\title{
Effects of a lipid-encapsulated zinc oxide supplement on growth performance and intestinal morphology and digestive enzyme activities in weanling pigs
}

Insurk Jang ${ }^{1}$, Chang Hoon Kwon², Duck Min Ha', Dae Yun Jung ${ }^{1}$, Sun Young Kang ${ }^{1}$, Man Jong Park', Jeong Hee Han², Byung-Chul Park ${ }^{3}$ and Chul Young Lee 1* $^{*}$

\begin{abstract}
This study compared the effects of varying lipid content and dietary concentration of a lipid-encapsulated (LE) $\mathrm{ZnO}$ product to those of native $\mathrm{ZnO}$ and thereby to find insights into optimal lipid coating and dosage of the $\mathrm{Zn}$ supplement. A total of 192 21-d-old weanling pigs were allotted to 48 pens, after which each six pens received a ZnO-free basal diet supplemented with 125 ppm ZnO (100 ppm Zn; BASAL), 2,500 ppm Zn as native ZnO (HIGH), or 100 or 200 ppm Zn as LE ZnO (LE-100 or LE-250) containing 8\%, 10\%, or 12\% lipid [LE-8\%, LE-10\%, or LE-12\%, respectively; $2 \times 3$ factorial arrangement within the LE-ZnO diets (LE-ALL)] for $14 \mathrm{~d}$. Forty pigs were killed at the end for histological and biochemical examinations. None of ADG, ADFI, gain:feed, and fecal consistency score differed between the LE-ALL and either of the BASAL and HIGH groups. Hepatic and serum Zn concentrations were greater ( $p<0.05$ ) in the HIGH vs. LE-ALL group, but did not differ between LE-ALL and BASAL, between LE-100 and -250, or among LE-8\%, -10\%, and $-12 \%$ groups. Villus height (VH), crypt depth (CD), and the VH:CD ratio in the duodenum, jejunum, and ileum did not differ between the LE-ALL and either of the BASAL and HIGH groups, except for a greater CD in the duodenum in the LE-ALL vs. HIGH group. Additionally, VH and CD in the duodenum and VH:CD in the jejunum were greater in the LE-250 vs. LE-100 group. Specific activities of sucrase, maltase, and leucine aminopeptidase in these intestinal regions and those of amylase and trypsin in the pancreas were not influenced by the lipid content or dietary concentration of LE ZnO and also did not differ between the LE-ALL and either of the BASAL and HIGH groups, except for a greater pancreatic amylase activity in the former vs. HIGH group. In conclusion, the present results indicate that the LE ZnO, regardless of its lipid percentage or supplementation level examined in this study, has no significant effect on growth performance, fecal consistency, or digestive enzyme activities of weanling pigs under the experimental conditions.
\end{abstract}

Keywords: Weanling pig, Zinc oxide, Dietary supplement, Growth, Diarrhea, Villus structure, Digestive enzyme

\section{Background}

Zinc oxide $(\mathrm{ZnO})$ is commonly supplemented to the pig starter diet to 2,000 to $3,000 \mathrm{ppm}$ to prevent the postweaning diarrhea as well as to enhance transiently retarded growth of post-weaning pigs [1-3]. However, supplementation of $\mathrm{ZnO}$ at this pharmacological level poses substantial concerns about environmental pollution, because dietary

\footnotetext{
* Correspondence: cylee@gntech.ac.kr

${ }^{1}$ The Regional Animal Industry Center, Gyeongnam National University of Science and Technology, Jinju 660-758, Republic of Korea

Full list of author information is available at the end of the article
}

$\mathrm{ZnO}$ is mostly unabsorbed and therefore excreted into the environment via feces $[4,5]$. This has led to limiting the in-feed $\mathrm{ZnO}$ concentration within $150 \mathrm{ppm}$ by legislation in the European Union. Accordingly, some manufacturers have lately introduced new $\mathrm{ZnO}$ products which are more active or more efficiently delivered to the intestine than conventionally used $\mathrm{ZnO}$, thereby suggesting the possibility of reducing the amount of $\mathrm{ZnO}$ added to the diet by substitution of the former for the latter.

A few types of non-covalent $\mathrm{ZnO}$-carrier conjugates have been manufactured as a means of increasing the 
efficiency of $\mathrm{ZnO}$ delivery. In this regard, $\mathrm{Hu}$ et al. [6-8] have reported that 600 to $900 \mathrm{ppm}$ supplementation of $\mathrm{Zn}$ as $\mathrm{ZnO}$ supported on zeolite or $500 \mathrm{ppm}$ of $\mathrm{Zn}$ as a $\mathrm{ZnO}$-smectite conjugate was as effective as 2,000 to 2,250 ppm of $\mathrm{Zn}$ as native $\mathrm{ZnO}$ in enhancing growth performance and digestive function of weanling pigs. HiZox (Animine, France) is also a $\mathrm{ZnO}$ product whose surface area is maximized to increase the bioavailability of the compound. As for its relative potency, Morales et al. [9] have reported that post-weaning pigs fed a diet supplemented with $110 \mathrm{ppm}$ of $\mathrm{Zn}$ as HiZox exhibited a greater ADG, a greater G:F ratio, and a better health status than those fed the same diet supplemented with 2,500 ppm of $\mathrm{Zn}$ as $\mathrm{ZnO}$; however, this needs to be confirmed.

The $\mathrm{ZnO}$ particle has also been coated with an enteric substance to increase the delivery of the mineral to the intestine [10-12]. Shield Zn (CTCBIO, Inc., Seoul) is a lipid-encapsulated $\mathrm{ZnO}$ product, which has been manufactured based on a rationale that the encapsulated $\mathrm{ZnO}$ particle reaches the intestine efficiently and is subsequently released upon digestion of the lipid capsule by lipase because unlike the inorganic $\mathrm{ZnO}$, the mineral component of the product is not released as $\mathrm{Zn}^{2+}$ under acidic $\mathrm{pH}$ in the stomach owing to the outer enteric coating [12]. In this connection, we have found that dietary supplementation of $72 \mathrm{ppm}$ of $\mathrm{Zn}$ as the LE $\mathrm{ZnO}$ (100 ppm) was as effective as 2,000 ppm of $\mathrm{Zn}$ as native $\mathrm{ZnO}(2,500 \mathrm{ppm})$ in alleviating reduced growth, diarrhea, and impaired integrity of intestinal mucosal structure in weanling pigs artificially infected with enterotoxigenic Escherichia coli (ETEC) K88 [11]. The present study was undertaken to investigate the effects of the $\mathrm{LE} \mathrm{ZnO}$ relative to those of native $\mathrm{ZnO}$ as well as the effects of the lipid content and dietary concentration of the $\mathrm{LE} \mathrm{ZnO}$ on growth and the measures of digestive function as an initial step to finding the optimal lipid coating and dosage of the $\mathrm{Zn}$ supplement in naïve weanling pigs.

\section{Methods}

\section{Animals}

The protocol for the present experiment was approved by the Institutional Animal Care and Use Committee (IACUC) of Gyeongnam National University of Science and Technology. The (Yorkshire $\times$ Landrace $) \times$ Duroc piglets were divided into the high-, medium- and low-body weight categories at weaning at 21 days of age. Ninety-six high- and 96 medium-body weight weanling pigs were randomly allotted to 48 pens by body weight to forty-eight $1-\mathrm{m}^{2}$ nursery pens, with two females and two castrated males housed per pen equipped with a feeder and a nipple waterer. Each six pens received a $\mathrm{ZnO}$-free basal nursery diet supplemented with $125 \mathrm{ppm}$ of native $\mathrm{ZnO}$ (100 ppm $\mathrm{ZnO}$; BASAL), 3,125 ppm of native $\mathrm{ZnO}$ (HIGH), 100 or
$200 \mathrm{ppm} \mathrm{Zn}$ as LE ZnO (LE-100 or LE-250) containing $8 \%, 10 \%$, or $12 \%$ lipid [LE- $8 \%, \mathrm{LE}-10 \%$, or LE- $12 \%$, respectively; $2 \times 3$ factorial arrangement within the LE$\mathrm{ZnO}$ diets (LE-ALL)] for $14 \mathrm{~d}$ (Table 1). The basal diet was formulated to contain a low percentage of crude protein to reduce the post-weaning diarrhea resulting from undigested proteins $[10,13]$. The ambient temperature was maintained at $30^{\circ} \mathrm{C}$ up to $\mathrm{d} 7$ and then lowered to $29^{\circ} \mathrm{C}$. Fecal consistency was scored on d 1, 4, 7, and 14 according to an arbitrary 3-point integer scale as described by Heo et al. [13] and Zhao et al. [14]: 1, well-formed feces; 2 , sloppy feces; 3 , diarrhea.

\section{Collection of blood samples and intestinal tissues}

A total of 40 pigs, which consisted of 16 pigs from the BASAL and HIGH groups (8 pigs each) and 24 pigs from the 6 LE groups (4 pigs each), were sacrificed as described previously [15]. Blood, pancreas, and intestinal tissues at the regions of the duodenum, jejunum, and ileum were collected also as described $[11,15]$.

\section{Determination of $\mathbf{Z n}$}

Five grams of hepatic tissue or $1 \mathrm{~mL}$ of serum was digested with $10 \mathrm{~mL}$ of $70 \%$ nitric acid at $150^{\circ} \mathrm{C}$ to complete solublization, filtered and diluted with $100 \mathrm{~mL}$ of distilled water. The $\mathrm{Zn}$ content in the digested and diluted solution was determined using an inductively coupled plasma atomic emission spectrophotometer (model 5300DV, Perkin-Elmer, Waltham, MA, USA).

\section{Histological and biochemical determinations}

The intestinal tissue was fixed, embedded in paraffin, mounted on the glass slide, stained, and subjected to microscopic determination of the villus height and crypt depth as described previously $[11,15]$.

The intestinal mucosa and pancreatic tissue were homogenized and stored at $-70^{\circ} \mathrm{C}$ until used. The protein content of the homogenate was determined using the bicinchronic acid protein assay kit (Pierce, Rockford, IL, USA); the specific activities of sucrase, maltase, leucine

\section{Table 1 Calculated chemical composition of the basal} diet $^{1)}$ (as-fed basis)

\begin{tabular}{lc}
\hline Item & Content \\
\hline $\mathrm{DE}, \mathrm{MCal} / \mathrm{kg}$ & 3.34 \\
Crude protein (\%) & 16.50 \\
Ether extract (\%) & 3.91 \\
Lysine (\%) & 1.21
\end{tabular}

Zn (ppm) 100,250 , or 2,500

${ }^{1)}$ The composition of ingredients, which was grains-soy-whey-based, was reported previously [11]. Experimental diets were manufactured by supplementing the basal diet containing no $\mathrm{Zn}$ additive with 125 or 3,125 ppm of native $\mathrm{ZnO}$ or 139 to 355 ppm of Shield $Z n^{\oplus}$ (CTCBIO, Seoul) encapsulated with $8 \%, 10 \%$, or $12 \%$ lipid (w/w) to provide 100,250 , or $2,500 \mathrm{ppm}$ of $\mathrm{Zn}$. 
aminopeptidase, and trypsin were determined as described previously [15-17].

\section{Statistical analysis}

All data were analyzed using the MIXED procedure of SAS (SAS Inst. Inc., Cary, NC, USA). The pen was the experimental unit in all variables, except for postmortem measurements in which the piglet was regarded as the experimental unit. The model included each dietary treatment as the main effect. In the analysis of repeated measurements, effects of the day and its interaction with the main effect were also included in the model. Accordingly, effects of the diet and the day including its interaction with the diet were tested using the experimental unit and experimental unit $x$ day as error terms, respectively. In addition, effects of supplementation of $\mathrm{LE} \mathrm{ZnO}$ vs. native $\mathrm{ZnO}$ as well as those of the lipid percentage and supplementation level of $\mathrm{LE} \mathrm{ZnO}$ were analyzed by the contrast.

\section{Results}

Growth performance including the average daily gain (ADG), average daily feed intake (ADFI), and gain:feed (G:F) ratio during the 14-d experimental period did not differ between the LE-ALL group and either of the BASAL and HIGH groups (Table 2). Moreover, within the LE-ALL group animals, the performance parameters were not different between the LE-10\% group and either of the LE-8\% and LE-12\% groups or between the LE-100 and LE-250 groups.

The majority of the piglets exhibited well-formed feces throughout the experimental period, although the fecal consistency score $(\mathrm{FCS})$ was greater $(P<0.01)$ on $\mathrm{d} 14$ than at any other time point (Table 2). However, the FCS did not differ between the LE-ALL group and either of the LBASAL and HIGH groups, between the LE-10\% group and either of the LE- $8 \%$ and $-12 \%$ groups, or between the LE-100 and -250 groups.

The $\mathrm{Zn}$ concentration in the liver did not differ between the LE-ALL and BASAL groups (Table 3). However, hepatic $\mathrm{ZnO}$ concentration was 11 -fold greater in the HIGH vs. LE-ALL group whereas within the LE-ALL group, it was not influenced by the lipid percentage or supplementation level of the LE $\mathrm{ZnO}$. Serum $\mathrm{Zn}$ concentration, which did not differ between the LE-ALL and BASAL groups, was marginally greater in the HIGH group vs. LEALL ( 2.45 vs. $1.49 \mu \mathrm{g} / \mathrm{mL} ; P<0.01)$. However, within the LE-ALL group, serum $\mathrm{Zn}$ concentration was not influenced by the lipid percentage or supplementation level of the $\mathrm{ZnO}$ product.

The villus height $(\mathrm{VH})$ and crypt depth $(\mathrm{CD})$ in the LE-ALL group were not different from those in the BASAL and HIGH groups in the duodenum (Table 3). Within the LE-ALL group, these morphology variables did not change due to a change in the lipid percentage of the $\mathrm{LE} \mathrm{ZnO}$, but increased when the supplementation

Table 2 Effects of supplementations of native $\mathrm{ZnO}$ and lipid-encapsulated $\mathrm{ZnO}$ (LE ZnO) on growth and fecal consistency of weanling pigs ${ }^{1)}$

\begin{tabular}{|c|c|c|c|c|c|c|c|c|c|c|c|c|c|c|c|}
\hline \multirow[t]{4}{*}{ Variable } & \multicolumn{10}{|c|}{ Dietary supplementation (ppm as Zn) } & \multicolumn{5}{|c|}{ Contrast $P$-value } \\
\hline & \multicolumn{2}{|c|}{ Native $\mathrm{ZnO}$} & \multicolumn{6}{|c|}{ LE ZnO } & \multirow{3}{*}{ SEM } & \multirow{3}{*}{$P$-value } & \multirow{2}{*}{\multicolumn{2}{|c|}{$\begin{array}{l}\text { LE ZnO vs. } \\
\text { Native ZnO }\end{array}$}} & \multicolumn{3}{|c|}{ Within LE ZnO } \\
\hline & \multirow[t]{2}{*}{100} & \multirow[t]{2}{*}{2,500} & \multicolumn{2}{|c|}{$8 \%$ lipid $^{2)}$} & \multicolumn{2}{|c|}{$10 \%$ lipid $^{2)}$} & \multicolumn{2}{|c|}{$12 \%$ lipid $^{2)}$} & & & & & \multicolumn{2}{|c|}{$10 \%$ lipid vs. } & \multirow{2}{*}{$\begin{array}{c}100 \mathrm{vs} \\
250\end{array}$} \\
\hline & & & 100 & 250 & 100 & 250 & 100 & 250 & & & 100 & 2,500 & $8 \%$ & $12 \%$ & \\
\hline \multicolumn{16}{|c|}{ Growth performance } \\
\hline Initial BW (kg) & 6.69 & 6.98 & 6.76 & 6.67 & 6.71 & 6.65 & 6.74 & 6.73 & 0.15 & 0.85 & 0.92 & 0.05 & 0.78 & 0.67 & 0.63 \\
\hline Final BW (kg) & 9.63 & 9.89 & 9.65 & 9.35 & 9.52 & 9.18 & 9.65 & 9.73 & 0.20 & 0.32 & 0.65 & 0.14 & 0.52 & 0.15 & 0.34 \\
\hline ADG (g) & 210 & 207 & 207 & 192 & 201 & 180 & 208 & 214 & 11 & 0.49 & 0.50 & 0.60 & 0.49 & 0.11 & 0.34 \\
\hline ADFI (g) & 355 & 367 & 355 & 329 & 344 & 327 & 348 & 369 & 13 & 0.24 & 0.49 & 0.13 & 0.60 & 0.09 & 0.51 \\
\hline$G: F$ & 0.591 & 0.569 & 0.582 & 0.586 & 0.581 & 0.538 & 0.603 & 0.579 & 0.025 & 0.76 & 0.63 & 0.74 & 0.34 & 0.21 & 0.30 \\
\hline \multicolumn{16}{|c|}{ Fecal consistency score ${ }^{3)}$} \\
\hline Day 1 & 1.00 & 1.00 & 1.00 & 1.00 & 1.00 & 1.00 & 1.00 & 1.00 & & & & & & & \\
\hline Day 4 & 1.00 & 1.13 & 1.08 & 1.00 & 1.00 & 1.13 & 1.04 & 1.04 & $0.07^{\mathrm{a}}$ & & & & & & \\
\hline Day 7 & 1.04 & 1.00 & 1.04 & 1.00 & 1.04 & 1.13 & 1.13 & 1.17 & & & & & & & \\
\hline Day 14 & 1.17 & 1.00 & 1.17 & 1.17 & 1.25 & 1.35 & 1.17 & 1.08 & & & & & & & \\
\hline Overall ${ }^{4)}$ & 1.05 & 1.03 & 1.07 & 1.04 & 1.07 & 1.15 & 1.08 & 1.07 & 0.04 & 0.59 & 0.35 & 0.11 & 0.07 & 0.27 & 0.63 \\
\hline
\end{tabular}

${ }^{1)}$ Data are means of 6 pens in each dietary group.

${ }^{2)}$ Denotes the percentage of lipid ( $\mathrm{w} / \mathrm{w}$ ) encapsulating the $\mathrm{ZnO}$ particle.

${ }^{3)}$ Scored according to a 3-notch integer scale: 1, well formed; 2, sloppy; 3, diarrhea.

${ }^{4)} P$-values for the day and day $\times$ treatment were $<0.01$ and 0.71 , respectively.

${ }^{a}$ Applies to all day $\times$ treatment combinations.

BW, body weight; ADG, average daily gain; $A D F I$, average daily feed intake; G:F, gain:feed. 
Table 3 Effects of dietary supplementations of native ZnO and lipid-encapsulated ZnO (LE ZnO) on hepatic and circulating $\mathrm{Zn}$ concentrations, intestinal villus structure, and specific activities of digestive enzymes in weanling pigs

\begin{tabular}{|c|c|c|c|c|c|c|c|c|c|c|c|c|c|c|c|c|}
\hline \multirow[t]{4}{*}{ Enzyme } & & & & \multicolumn{8}{|c|}{ Dietary supplementation (ppm as $\mathrm{Zn}$ ) } & \multicolumn{5}{|c|}{ Contrast $P$-value } \\
\hline & \multicolumn{3}{|c|}{ Native $\mathrm{ZnO}^{1)}$} & \multicolumn{7}{|c|}{ LE ZnO } & \multirow{3}{*}{$P$-value } & \multirow{2}{*}{\multicolumn{2}{|c|}{$\begin{array}{l}\text { LE ZnO vs. } \\
\text { Native ZnO }\end{array}$}} & \multicolumn{3}{|c|}{ Within LE ZnO } \\
\hline & \multirow[t]{2}{*}{100} & \multirow[t]{2}{*}{2,500} & \multirow[t]{2}{*}{$\overline{\text { SEM }}$} & \multicolumn{2}{|c|}{$8 \%$ lipid $^{2)}$} & \multicolumn{2}{|c|}{$10 \%$ lipid $^{2)}$} & \multicolumn{2}{|c|}{$12 \%$ lipid $^{2)}$} & \multirow[t]{2}{*}{$\overline{\text { SEM }}$} & & & & \multicolumn{2}{|c|}{$10 \%$ lipid vs. } & \multirow{2}{*}{$\begin{array}{c}100 \mathrm{vs} \\
250\end{array}$} \\
\hline & & & & 100 & 250 & 100 & 250 & 100 & 250 & & & 100 & 2,500 & $8 \%$ & $12 \%$ & \\
\hline \multicolumn{17}{|l|}{ Zn concentration } \\
\hline Liver $(\mu \mathrm{g} / \mathrm{g})$ & 34.9 & 412.1 & 13.6 & 33.3 & 55.4 & 27.8 & 33.5 & 36.3 & 39.0 & 19.2 & $<0.01$ & 0.87 & $<0.01$ & 0.48 & 0.72 & 0.52 \\
\hline Serum $(\mu \mathrm{g} / \mathrm{ml})$ & 1.78 & 2.45 & 0.14 & 1.53 & 1.63 & 1.52 & 1.50 & 1.14 & 1.62 & 0.22 & $<0.01$ & 0.10 & $<0.01$ & 0.75 & 0.57 & 0.31 \\
\hline \multicolumn{17}{|l|}{ Villus structure } \\
\hline \multicolumn{17}{|l|}{ Duodenum } \\
\hline $\mathrm{VH}(\mu \mathrm{m})$ & 292 & 284 & 14 & 299 & 365 & 299 & 315 & 277 & 323 & 20 & 0.07 & 0.21 & 0.10 & 0.22 & 0.71 & $<0.01$ \\
\hline$C D(\mu m)$ & 230 & 227 & 11 & 240 & 282 & 238 & 276 & 231 & 256 & 16 & 0.07 & 0.07 & 0.05 & 0.78 & 0.41 & $<0.01$ \\
\hline $\mathrm{VH}: \mathrm{CD}$ & 1.27 & 1.26 & 0.04 & 1.25 & 1.29 & 1.26 & 1.15 & 1.20 & 1.26 & 0.05 & 0.56 & 0.37 & 0.66 & 0.21 & 0.60 & 0.98 \\
\hline \multicolumn{17}{|l|}{ Jejunum } \\
\hline $\mathrm{VH}(\mu \mathrm{m})$ & 280 & 252 & 16 & 254 & 315 & 240 & 266 & 275 & 263 & 21 & 0.31 & 0.54 & 0.38 & 0.15 & 0.46 & 0.17 \\
\hline$C D(\mu m)$ & 230 & 206 & 15 & 234 & 262 & 225 & 238 & 251 & 218 & 20 & 0.49 & 0.64 & 0.08 & 0.44 & 0.89 & 0.87 \\
\hline $\mathrm{VH}: \mathrm{CD}$ & 1.21 & 1.16 & 0.03 & 1.09 & 1.20 & 1.07 & 1.12 & 1.11 & 1.20 & 0.04 & 0.03 & 0.02 & 0.30 & 0.21 & 0.13 & $<0.01$ \\
\hline \multicolumn{17}{|l|}{ Ileum } \\
\hline $\mathrm{VH}(\mu \mathrm{m})$ & 245 & 209 & 13 & 215 & 247 & 245 & 234 & 230 & 232 & 19 & 0.56 & 0.48 & 0.11 & 0.67 & 0.67 & 0.62 \\
\hline$C D(\mu m)$ & 228 & 186 & 13 & 205 & 221 & 238 & 224 & 238 & 180 & 19 & 0.15 & 0.73 & 0.05 & 0.33 & 0.24 & 0.24 \\
\hline $\mathrm{VH}: \mathrm{CD}$ & 1.10 & 1.21 & 0.07 & 1.30 & 1.16 & 1.03 & 1.05 & 1.09 & 1.31 & 0.11 & 0.36 & 0.54 & 0.50 & 0.08 & 0.15 & 0.71 \\
\hline
\end{tabular}

Enzyme activity $\left(\mu \mathrm{mol}\right.$ end product $\cdot \mathrm{mg}$ protein ${ }^{-1} \cdot \mathrm{min}^{-1}$ )

\begin{tabular}{|c|c|c|c|c|c|c|c|c|c|c|c|c|c|c|c|c|}
\hline \multicolumn{17}{|l|}{ Sucrase } \\
\hline Duodenum & 0.043 & 0.034 & 0.008 & 0.076 & 0.039 & 0.040 & 0.049 & 0.041 & 0.044 & 0.012 & 0.25 & 0.61 & 0.14 & 0.26 & 0.89 & 0.39 \\
\hline Jejunum & 0.874 & 0.537 & 0.225 & 0.319 & 0.401 & 0.160 & 0.628 & 0.509 & 0.170 & 0.318 & 0.59 & 0.06 & 0.51 & 0.91 & 0.86 & 0.79 \\
\hline Ileum & 0.098 & 0.117 & 0.032 & 0.105 & 0.099 & 0.088 & 0.107 & 0.094 & 0.119 & 0.046 & 1.00 & 0.91 & 0.68 & 0.93 & 0.86 & 0.74 \\
\hline \multicolumn{17}{|l|}{ Maltase } \\
\hline Duodenum & 5.18 & 4.41 & 1.10 & 8.15 & 4.56 & 5.98 & 7.71 & 5.34 & 7.80 & 1.56 & 0.36 & 0.28 & 0.10 & 0.76 & 0.86 & 0.88 \\
\hline Jejunum & 15.87 & 12.70 & 3.48 & 8.35 & 12.95 & 10.28 & 14.10 & 13.88 & 5.38 & 4.92 & 0.76 & 0.22 & 0.64 & 0.76 & 0.61 & 0.99 \\
\hline Ileum & 4.20 & 5.39 & 1.49 & 5.11 & 4.02 & 2.91 & 6.27 & 4.13 & 3.95 & 2.11 & 0.96 & 0.91 & 0.57 & 0.99 & 0.80 & 0.69 \\
\hline \multicolumn{17}{|l|}{ LAP } \\
\hline Duodenum & 2.00 & 2.30 & 0.36 & 2.19 & 1.91 & 1.99 & 2.72 & 1.90 & 3.20 & 0.50 & 0.53 & 0.45 & 0.96 & 0.55 & 0.70 & 0.17 \\
\hline Jejunum & 3.15 & 2.73 & 0.27 & 2.37 & 2.53 & 3.17 & 2.51 & 3.25 & 2.20 & 0.38 & 0.30 & 0.14 & 0.86 & 0.31 & 0.77 & 0.11 \\
\hline Ileum & 1.76 & 1.93 & 0.29 & 2.04 & 1.71 & 1.68 & 1.94 & 1.61 & 1.81 & 0.41 & 0.99 & 0.90 & 0.69 & 0.88 & 0.81 & 0.89 \\
\hline Amylase (PAN) & 241.2 & 142.1 & 23.0 & 262.1 & 185.1 & 224.3 & 240.7 & 237.6 & 231.4 & 31.4 & 0.06 & 0.67 & $<0.01$ & 0.78 & 0.95 & 0.39 \\
\hline Trypsin (PAN) & 0.156 & 0.107 & 0.022 & 0.149 & 0.127 & 0.150 & 0.184 & 0.160 & 0.197 & 0.032 & 0.43 & 0.86 & 0.06 & 0.37 & 0.71 & 0.53 \\
\hline
\end{tabular}

${ }^{1)}$ Data are means of 8 animals in each group.

${ }^{2)}$ Denotes the percentage of lipid ( $\mathrm{w} / \mathrm{w}$ ) encapsulating the $\mathrm{ZnO}$ particle. Data are means of 4 animals in each group. $V H$, villus height; $C D$, crypt depth; $L A P$, leucine aminopeptidase; PAN, pancreas.

level was increased from $100 \mathrm{ppm} \mathrm{Zn}$ to $250 \mathrm{ppm}$ $(P<0.01)$. However, the $\mathrm{VH}: \mathrm{CD}$ ratio in the duodenum did not differ between the LE-ALL group and either of the BASAL and HIGH groups, between the LE-10\% group and either of the LE- $8 \%$ and $-12 \%$ groups, or between the LE-100 and -250 groups. In the jejunum, the $\mathrm{VH}$ and $\mathrm{CD}$ did not differ between the LE-ALL group and either of the BASAL and HIGH groups and also were not influenced by the lipid percentage or supplementation level of the $\mathrm{LE} \mathrm{ZnO}$. However, the $\mathrm{VH}: \mathrm{CD}$ ratio was greater $(P<0.05)$ in the BASAL group $(1.21)$ than in the LE-ALL group (1.13), within which it was greater $(P<0.01)$ in the LE-250 vs. LE-100 group $(1.17$ vs. 1.09). In the ileum, the $C D$ was greater in the LEALL vs. HIGH group (218 vs. $186 \mu \mathrm{m}$ ); otherwise, the villus morphology variables did not differ between the 
LE-ALL group and either of the BASAL and HIGH groups, between the LE-100 and -250 groups, or among the LE- $8 \%,-10 \%$, and $-12 \%$ groups.

Specific activities of sucrase, maltase, and leucine aminopeptidase in the mucosa were not affected by any treatment factor examined in the present study in any intestinal segment (Table 3). Specific activities of amylase and trypsin in the pancreas also did not change due to any treatment factor, except for a greater amylase activity in the LE-ALL vs. HIGH group.

\section{Discussion}

The present results indicated that neither supplementation level of native $\mathrm{ZnO}$ or $\mathrm{LE} \mathrm{ZnO}$ nor lipid percentage of the latter has any significant effect on ADG, ADFI, G: F, or FCS. However, this does not necessarily mean that neither pharmacological supplementation of native $\mathrm{ZnO}$ nor the basal-level supplementation of LE $\mathrm{ZnO}$ has any significant effect on these performance parameters, because even the known growth-enhancing effect of the former $[2,3,18,19]$ was not apparent under the present experimental conditions. As a matter of fact, we have observed a growth-enhancing effect of the LE $\mathrm{ZnO}$ supplemented at a basal level (100 ppm as Zn concentration; unpublished results). The lack of growth-enhancing effects of the LE $\mathrm{ZnO}$ and HIGH treatments in the present study is therefore reflective of the known fact that growth enhancers including $\mathrm{ZnO}$ are less effective under experimental settings than under production conditions $[20,21]$. In this context, the present results were also reminiscent of the lack of effects of the in-feed antibiotics, the known growth enhancers in swine [20,21], on growth performance of post-weaning pigs placed in small experimental pens in our previous study [15]. As such, more studies are warranted to determine the optimal usage of the $\mathrm{LE} \mathrm{ZnO}$ as a growth-enhancing dietary supplement for weanling pigs under production conditions.

The several-fold and marginally greater $\mathrm{Zn}$ concentrations in the HIGH vs. BASAL group in the liver and serum, respectively, were consistent with published results [22-24]. Moreover, neither circulating Zn concentration was different between the $\mathrm{LE} \mathrm{ZnO}$ and BASAL groups as in a report of Kim et al. [10], nor hepatic Zn concentration was influenced by the lipid coating. These results imply that the supplementation level of $\mathrm{ZnO}$ is well reflected into the $\mathrm{Zn}$ concentration in the liver where many heavy metals are stored and that the absorption rate of $\mathrm{Zn}$ at the intestine is not influenced by lipid coating of the $\mathrm{ZnO}$ particle.

The lack of effect of the LE $\mathrm{ZnO}$ or HIGH treatment on the intestinal villus structure was quite different from the increase in the $\mathrm{VH}$ and/or $\mathrm{VH}: \mathrm{CD}$ ratio as well as the decrease in $\mathrm{CD}$ in response to either treatment in weanling pigs artificially infected with ETEC K88 in our previous study [11]. Furthermore, the positive effect of pharmacological $\mathrm{ZnO}$ on the integrity of the villus structure often observed in weanling pigs [25-27] also was not apparent in the present study. These results are thus interpreted to suggest that the beneficial effect of either $\mathrm{Zn}$ supplement on the integrity of the villus may be apparent only when the villus structure of the piglet is substantially damaged by any causative like the microbial infection. In this context, the increased $\mathrm{VH}$ in the duodenum and increased $\mathrm{VH}: \mathrm{CD}$ in the jejunum in response to the LE-250 treatment vs. LE-100 observed in the present study, albeit intriguing, needs to be rigorously confirmed to make any firm conclusion as to the dose effect of the $\mathrm{LE} \mathrm{ZnO}$ on the villus structure in naïve weanling pigs.

Results on the digestive enzyme activities in the intestinal mucosa and pancreatic tissue also indicated that these are not affected by the supplementation level of the $\mathrm{LE} \mathrm{ZnO}$ or native $\mathrm{ZnO}$ or by the lipid percentage of the former, although the pancreatic amylase activity was greater in the LE-ALL vs. HIGH group. Similarly, in the study of Hedemann et al. [28], effects of the high- $\mathrm{ZnO}$ $(2,500 \mathrm{ppm}$ as $\mathrm{Zn})$ diet on pancreatic and intestinal enzyme activities in weanling pigs were inconclusive or equivocal.

\section{Conclusions}

The present results indicated that neither the high- $\mathrm{ZnO}$ supplementation nor the physiolgical supplementation of the $\mathrm{LE} \mathrm{ZnO}$ containing 8 to $12 \%$ lipid to 100 or $250 \mathrm{ppm}$ Zn has any significant effect on growth performance, fecal consistency, villus morphology, or digestive enzyme activities of the piglets under the experimental conditions. More studies are necessary, however, to determine the effects of the $\mathrm{LE} \mathrm{ZnO}$ relative to those of native $\mathrm{ZnO}$ on these measures in weanling pigs under production conditions.

\section{Competing interests \\ The authors declare that they have no competing interests.}

\section{Authors' contributions}

$\mathrm{BCP}$ and $\mathrm{CYL}$ designed the experiment and analyzed the data. $\mathrm{DMH}, \mathrm{DY}$, MJP, and CYL managed the experimental animals. CHK and JHH analyzed the intestinal morphology. SYK and IJ determined the enzyme activities. All authors read and approved the final manuscript.

\section{Acknowledgements}

This work was supported by CTCBIO, Inc. and the Regional Animal Industry Center at Gyeongnam National University of Science and Technology.

\section{Author details}

${ }^{1}$ The Regional Animal Industry Center, Gyeongnam National University of Science and Technology, Jinju 660-758, Republic of Korea. ${ }^{2}$ College of Veterinary Medicine and Institute of Veterinary Science, Kangwon National University, Chuncheon 200-701, Republic of Korea. ${ }^{3} \mathrm{R} \&$ D Institute, Sunjin Co., Ltd, 517-3 Doonchon-dong, Kangdong-gu, Seoul 134-060, Republic of Korea.

Received: 17 September 2014 Accepted: 5 November 2014 Published: 9 December 2014 


\section{References}

1. Heo JM, Opapeju FO, Pluske JR, Kim JC, Hampson DJ, Nyachoti CM: Gastrointestinal health and function in weaned pigs: a review of feeding strategies to control post-weaning diarrhoea without using in-feed antimicrobial compounds. J Anim Physiol Anim Nutr 2013, 97:207-237.

2. Hill GM: Minerals and Mineral Utilization in Swine. In Sustainable Swine Nutrition. Edited by Chiba LI. Oxford: John Wiley \& Sons, Inc; 2013:173-195.

3. Sales J: Effect of pharmacological concentrations of dietary zinc oxide on growth of post-weaning pigs: a meta-analysis. Biol Trace Elem Res 2013, 152:343-349.

4. Poulsen $H D$, Larsen $T$ : Zinc excretion and retention in growing pigs fed increasing levels of zinc oxide. Livest Prod Sci 1995, 43:235-242.

5. Jondreville C, Revy PS, Dourmad JY: Dietary means to better control the environmental impact of copper and zinc by pigs from weaning to slaughter. Livest Prod Sci 2003, 84:147-156.

6. Hu CH, Gu LY, Luan ZS, Song J, Zhu K: Effects of montmorillonite-zinc oxide hybrid on performance, diarrhea, intestinal permeability and morphology of weanling pigs. Anim Feed Sci Technol 2012, 177:108-115.

7. Hu C, Song J, Li Y, Luan Z, Zhu K: Diosmectite-zinc oxide composite improves intestinal barrier function, modulates expression of pro-inflammatory cytokines and tight junction protein in early weaned pigs. Br J Nutr 2013, 110:681-688.

8. Hu CH, Xiao K, Song J, Luan ZS: Effects of zinc oxide supported on zeolite on growth performance, intestinal microflora and permeability, and cytokines expression of weaned pigs. Anim Feed Sci Technol 2013, 181:65-71.

9. Morales J, Cordero G, Pineiro C, Durosoy S: Zinc oxide at low supplementation improves productive performance and health status of piglets. J Anim Sci 2012, 90(Suppl 4):436-438.

10. Kim JC, Hansen CF, Mullan BP, Pluske JR: Nutrition and pathology of weaner pigs: nutritional strategies to support barrier function in the gastrointestinal tract. Anim Feed Sci Technol 2012, 173:3-16.

11. Kwon CH, Lee CY, Han SY, Kim SJ, Park BC, Jang I, Han JH: Effects of dietary supplementation of lipid-encapsulated zinc oxide on colibacillosis, growth and intestinal morphology in weaned piglets challenged with enterotoxigenic Escherichia coli. Anim Sci J 2014, 85:805-813.

12. Shen J, Chen Y, Wang Z, Zhou A, He M, Mao L, Zou H, Peng Q, Xue B, Zhang $X$, Wu S, LV Y: Coated zinc oxide improves intestinal immunity function and regulates microflora composition in weaned piglets. $\mathrm{Br} J$ Nutr 2014, 111:2123-2134.

13. Heo JM, Kim JC, Hansen CF, Mullan BP, Hampson DJ, Pluske JR: Feeding a diet with decreased potein content reduces indices of protein fermentation and the incidence of postweaning diarrhea in weaned pigs challenged with an enterotoxigenic strain of Escherichia coli. J Anim Sci 2009, 87:2833-2843

14. Zhao PY, Jung JH, Kim IH: Effect of mannan oligosaccharides and fructan on growth performance, nutrient digestibility, blood profile, and diarrhea score in weanling pigs. J Anim Sci 2012, 90:833-839.

15. Lee CY, Lim JW, Ko YH, Kang SY, Park MJ, Ko T, Lee JH, Hyun Y, Jeong KS, Jang IS: Intestinal growth and deveopment of weanling pigs in response to dietary supplementation of antibiotics, phytogenic products and brewer's yeast plus Bacillus spores. J Anim Sci Technol 2011, 53:227-235.

16. Jang IS, Ko YH, Yang HY, Ha JS, Kim JY, Kim JY, Kang SY, Yoo DH, Nam DS, Kim DH, Lee CY: Influence of essential oil components on growth performance and the functional activity of the pancreas and small intestine in broiler chickens. Asian-Aust J Anim Sci 2004, 17:394-400.

17. Jang IS, Ko YH, Kang SY, Lee CY: Effect of a commercial essential oil on growth performance, digestive enzyme activity and intestinal microflora population in broiler chickens. Anim Feed Sci Technol 2007, 134:304-315.

18. Hahn JD, Baker DH: Growth and plasma zinc responses of young pigs fed pharmacologic levels of zinc. J Anim Sci 1993, 71:3020-3024.

19. Hill GM, Mahan DC, Carter SD, Cromwell GL, Ewan RC, Harrold RL, Lewis AJ, Miller PS, Shurson GC, Veum TL: Effect of pharmacological concentrations of zinc oxide with or without the inclusion of an antibacterial agent on nursery pig performance. J Anim Sci 2001, 79:934-941.

20. Cromwell GL: Antimicrobial and promicrobial agents. In Swine Nutrition. 2nd edition. Edited by Chiba LI. Oxford: John Wiley \& Sons, Inc; 2001:401-426.

21. Wenk $C$ : Recent advances in animal feed additives such as metabolic modifiers, antimicrobial agents, probiotics, enzymes and highly available minerals - review. Asian-Aust J Anim Sci 2000, 13:86-95.

22. Jensen-Waern $M$, Melin $L$, Lindberg $R$, Johannisson A, Petersson $L$, Wallgren PP: Dietary zinc oxide in weaned pigs - effects on performance, tisue concentrations, morphology, neutrophil functions and faecal microflora. Res Vet Sci 1998, 64:225-231.

23. Carlson D, Beattie JH, Poulsen HD: Assessment of zinc and copper status in weaned piglets in relation to dietary zinc and copper supply. J Anim Physiol Anim Nutr 2007, 91:19-28.

24. Davin R, Manzanilla EG, Klasing KC, Perez JF: Effect of weaning and in-feed high doses of zinc oxide on zinc levels in different body compartments of piglets. J Anim Physiol Anim Nutr 2013, 97:6-12.

25. Li BT, Van Kessel AG, Caine WR, Huang SX, Kirkwood RN: Small intestinal morphology and bacterial populations in ileal digesta and feces of newly weaned pigs receiving a high dietary level of zinc oxide. Can $J$ Anim Sci 2001, 81:511-516.

26. Li X, Yin J, Li D, Chen X, Zang J, Zhou X: Dietary supplementation with zinc oxide increases IGF-I and IGF-I receptor gene expression in the small intestine of weanling piglets. J Nutr 2006, 136:1786-1791.

27. Owusu-Asiedu A, Nyachoti CM, Marquardt RR: Response of early-weaned pigs to an enterotoxigenic Escherichia coli (K88) challenge when fed diets containing spray-dried porcine plasma or pea protein isolate plus egg yolk antibody, zinc oxide, fumaric acid, or antibiotic. J Anim Sci 2003, 81:1790-1798.

28. Hedemann MS, Jensen BB, Poulsen HD: Influence of dietary zinc and copper on digestive enzyme activity and intestinal morphology in weaned pigs. J Anim Sci 2006, 84:3310-3320.

doi:10.1186/2055-0391-56-29

Cite this article as: Jang et al:: Effects of a lipid-encapsulated zinc oxide supplement on growth performance and intestinal morphology and digestive enzyme activities in weanling pigs. Journal of Animal Science and Technology 2014 56:29.

\section{Submit your next manuscript to BioMed Central and take full advantage of:}

- Convenient online submission

- Thorough peer review

- No space constraints or color figure charges

- Immediate publication on acceptance

- Inclusion in PubMed, CAS, Scopus and Google Scholar

- Research which is freely available for redistribution 